\title{
Value Chain Analysis of Red Pepper: The Case of Mareko District, Guragie Zone, Southern Ethiopia
}

\author{
Mekdes Dessie ${ }^{1 *}$, Mufti Jailan ${ }^{1}$, Habtamu Mosi ${ }^{1}$ and Getachew Mekonnen ${ }^{2}$ \\ ${ }^{1}$ College of Agriculture and Natural Resources, Mizan Tepi University, Ethiopia \\ ${ }^{2}$ College of Agriculture and Natural Resources, Mizan Tepi University, Ethiopia
}

Submission: May 24, 2018, Published: July 18, 2018

"Corresponding author: Mekdes Dessie, College of Agriculture and Natural Resources, Wolkite University, Ethiopia, Email: dessiemekdes@yahoo.com

\begin{abstract}
The study was conducted at Mareko Woreda to undertake red pepper value chain analysis and examine the factors that affect the supply of red pepper. The area is known for its surplus production of red pepper. The study has focused on the market channel, conduct, performance of red pepper markets and the main constraints of volume of red pepper supply. Structured questionnaire, focus group discussions, key informant interviews and field observation were used for generating the data. The channel in which, retailers buy red pepper directly from farmers and they in turn sell the red pepper directly to the consumer's outlooks as the 1st important channel in the study area in terms of volume transacted. About $78.3 \%$ of the red pepper producers sold the red pepper by the price set of both parties based on negotiation. With regard to the payment strategy, about $79.17 \%$ of sample farmers sold their product on cash. Traders took a total of $87.75 \%$ out of the total profit margin; specifically, among traders, processors profit margin constitutes the highest share (30.71\%) followed by retailors $(20.49 \%)$. The result from the econometric analysis show that, education level of the household head, Average lagged price, Proportion of land allocated for red pepper production, experience of the house hold head were found to have positive influence on marketable supply of red pepper. Likewise, Average input price and diseases were found to influence marketable supply of negatively. producer share were smaller than traders so enhancing producers bargaining power through cooperative was important Marketing conduct shows that there was breed mix problem in the study area so that secured governments grant for mareko breed was essential.
\end{abstract}

Keywords: Mareko woreda; Marketing cost; Marketing margin; Profitability; Red pepper; Supply factors

Abbreviations: BoARD: Bureau of Agriculture and Rural Development; SPSS: Statistical Package for social Science; MRM: Multiple Regression Model; QSRP: Quantity of Red Pepper Supplied to the Market; EDLHH: Education Level of Household Head; PLAFRPP: Proportion of Land Allotted for Red Pepper Production; FAMSZ: Family Size of Household; DFM: Distance from Market; API: Average Input Price of Red Pepper; ALP: Average Lagged Price; DIS: Disease; EXPHH: Experience of Household Head on Red Pepper Production; VIF: Variance Inflation Factor; CC: Contingency Coefficient; BP: Breusch-Pagan; WLS: Weighted Least Squares; EUCHH: Education Level of the Household Head; ALP: Average Lagged Price

\section{Introduction}

In many developing countries including Ethiopia, agriculture plays a vibrant role in promoting economic growth and development. The importance of agriculture in Ethiopia is evidenced by its share in GDP (43\%), its employment generation (80\%), share of export $(70 \%)$ and providing about $70 \%$ raw material for the industries in the country in 2012/13 [1]. Furthermore, $90 \%$ of the poor earn their livelihood from this sector. Thus, it is not surprising that policy action in Ethiopia is largely based on influencing the dynamism of the agricultural sector.

The globalized markets demand consistent supply of higher quality products that meet new standards for food quality and safety and hence increase the comparative advantages of large scale commercial farmers, processors and supermarket chains.
Small and medium scale operators and smallholder farmers that supply them find it difficult to penetrate and exploit international markets which require value added products, in situations where local capacity and participation in the value addition process is limited by insufficient innovative product development and diversification to meet market requirements. The full exploitation of opportunities presented by these markets requires development of innovative market linkages and addressing specific consumer needs and diversification of agricultural products [2].

Ethiopia has a comparative advantage in a number of horticultural commodities due to its favorable climate, proximity to European and Middle Eastern markets and cheap labor. However, the production of horticultural crops is much less than the production of food grains in the country. On average, more 
than 2,399,566 tons of vegetables and fruits are produced by public and private commercial farms (less than $2 \%$ of the total crop production) [3].

The past history of pepper in Ethiopia is possibly the most earliest than any other vegetable product [4]. Ethiopians have strong attachment to red pepper, which has high value principally for its high pungency. The fine powdered pungent product is an indispensable flavoring and coloring ingredient in the common traditional sauce "Wot" whereas; the green pod is consumed as a vegetable with other food items. There is a general belief among Ethiopians that a person who frequently consumes hot pepper has resistance to various diseases. The average daily consumption of hot pepper by Ethiopian adult is estimated 15 gram, which is higher than tomatoes and most other vegetables [4].

Red pepper is a crop of high value in both domestic and export markets. Since it is an industrial crop, it generates employment to urban and rural workers. The main processed product, oleoresin, is exported to different countries and the spiced ground is supplied to local market. Oleoresin that is used for food coloring is extracted from red pepper for export purpose. The deep red colored cultivars have a very high processing demand in the country [4].

Farmers in Ethiopia are more focused on the production part without having adequate market information about their products. Agricultural marketing has become highly complex and difficult involving very large and long marketing channels, a large number of middlemen, many types of physical, social, economic and facilitating marketing functions and services. The majority of farmers are marginal, small, scattered, illiterate and unorganized. They do not have sufficient time, knowledge and skills for the scientific marketing of their produce. In the absence of welldeveloped markets, marketing facilities, and marketing efficiency, farmers are at disadvantage by selling their increased marketable surplus to traders in the market as they get low prices [2].

Red pepper is widely cultivated in different agro- ecologies of Ethiopia. The Ethiopian Export Promotion Agency [4] has carried out a spice potential market study in Amhara, Oromiya and SNNPRS, and it identified that the land coverage for pepper in the three regions. The total production of pepper in the country for the year 2016/2017 Ethiopian main cropping season (Meher) was estimated at 3.1 million quintals. On average $75 \%$ of pepper production is for market in SNNPRS [5]. The share of the region in the total production of red pepper in the country constitutes $69 \%$, followed by Amahara region, which produces about $27 \%$ of the total production in the country [5]. In 2014/2015 production year the total cultivated land and production in the region was 67,072 hectare and 1,970,068 quintal respectively [5].

The findings from this study are believed to be helpful in reducing the information gap on red pepper and contributing to work better understanding on improved strategies for reorienting marketing system for the benefit of smallholder farmers, traders, and other market participants. Analyzing the challenges in pepper marketing would indicate the gaps to improve pepper production and marketing and benefit policy makers and implementers in the area to fill the gaps. In addition to this it will also help to make appropriate marketing decisions by the producers, consumers, traders, investors, and others.

The study is also used to suggest strategies for smooth integration among production and marketing by referring to root causes for supply and marketing problems starting from production till the consumption of the product. In addition to this red pepper price currently increase more than previous time so study on value chain of red pepper today is important to identify whether producers gets the right share or not. This study, therefore, is initiated with the purpose of investigating the pepper value chains and factors affecting red pepper supply to the market in Mareko.

\section{Research Methodology \\ Description of the study area}

This study was conducted in five rural kebeles in Mareko woreda which is known for its red pepper production. Mareko is one of the woredas in the Southern Nations, Nationalities, and Peoples' Region of Ethiopia. Part of the Gurage Zone, It comprises 25 rural and one urban kebele administrations which are found in dry woinadega agro-ecological zone. The woreda is located about $136 \mathrm{~km}$ from the zonal capital, Wolkite. The woreda is bordered in the south by the Silte zone in the east and north by Oromia region, and in the west by Meskan woreda. The topography district is characterized by flat ( $80 \%)$ and hill (20\%) lands. The altitude of the district ranges between 1800 to 2076 meters above sea level.

\section{Sampling technique and sample size}

In this study a two-stage sampling technique was used to select red pepper producers. The district has one urban and 25 rural Kebles. In the first stage five major red peppers producing Kebles were selected purposively based on its potential for red pepper production and marketing. In the second stage among the households that exist in the five Kebles red pepper producers were selected using random sampling technique. Accordingly, the sample size for this study was based on the rule of thumb $\mathrm{N} \geq 50+8 \mathrm{~m}$; where ' $\mathrm{N}$ ' is sample size and ' $\mathrm{m}$ ' is the number of explanatory variables (Xi) where $\mathrm{i}=1,2 \ldots 11$ [6]. Hence, 120 respondents from five Kebles of Mareko woreda were selected and interviewed.

The trader surveys were conducted on market in urban areas/ towns in which a good sample of pepper traders existed. On the basis of flow of pepper, three markets (kosha, ensano, and butagira) were selected, which are the main pepper marketing sites in the study areas. An additional criterion used to select survey sites was the availability of secondary price data for some of the markets. 
Due to the absence of reliable information on the population of traders in these areas, cluster sampling technique was conducted in the selected markets.

Therefore, in this study an attempt was made to select representative sample whenever possible using cluster sampling by incorporating licensed and un-licensed traders, and to include respondents from each of the following categories: wholesalers, collector retailer and processor. The total number of traders interviewed was 25 ( 6 wholesalers, 9 retailers, 5 collectors and 5 processors). To interview traders an independent check list was prepared and used.

\section{Type, source and method of data collection}

In this study, both the primary and secondary data were used. The primary data were collected through a household survey, focus group discussions (two separate FGDs that each contains 12 members were held in kosha and ensano kebles on feb.2017. The discussion was facilitated by the researcher together with the BoARD expert.), key informant interviews (for this purpose key informants were selected from each kebele and a one-toone interview was conducted with the selected key informants.) and field observations. To generate relevant secondary data on red pepper production and marketing, data was collected from different published and unpublished sources such as government institutions; the Bureau of Agriculture and Rural Development (BoARD), Woreda marketing agency reports and websites were referred.

\section{Method of Data Analysis}

In this study two types of data analysis methods were used. These include descriptive statistics and econometric analysis. The

Table 1: Description of dependent and independent variables.

\begin{tabular}{|c|c|c|c|}
\hline Variables & Description of Variables & Unit of Measurement & Expected Sign \\
\hline $\begin{array}{l}\text { Quantity of red pepper supplied to the } \\
\text { Market (QSRP) }\end{array}$ & $\begin{array}{l}\text { Dependent variable indicating } \\
\text { quantity of red pepper supplied }\end{array}$ & C=kilogram & + \\
\hline Average lagged Price of red pepper (ALP) & $\begin{array}{l}\text { Average lagged Price of red pepper } \\
\text { per kilogram }\end{array}$ & $\mathrm{C}=\mathrm{ETB}$ & + \\
\hline Family Size (FAMSZ) & Household family size & $\mathrm{C}=\mathrm{Number}$ & $+/-$ \\
\hline Education (EDLHH) & $\begin{array}{l}\text { Educational status of the household } \\
\text { head }\end{array}$ & $\mathrm{C}=$ Year of schooling & + \\
\hline Distance from market (DFM) & Far to the market & $\mathrm{C}=$ kilometer & - \\
\hline $\begin{array}{l}\text { Proportion of Allotted land for red } \\
\text { pepper production (PALFRPP) }\end{array}$ & $\begin{array}{l}\text { Allotted land for red pepper } \\
\text { production }\end{array}$ & $\mathrm{C}=$ hectare & + \\
\hline Average input price of red pepper (API) & Input price for red pepper & $\mathrm{C}=\mathrm{ETB}$ & - \\
\hline Experience of household (EXPHH) & $\begin{array}{l}\text { experience of house hold head on } \\
\text { red pepper production }\end{array}$ & $\mathrm{C}=$ Year of experience & + \\
\hline Disease (DIS) & Occurrence of Diseases & $\begin{array}{l}\mathrm{D}=1 \text { if disease; }=0 \\
\text { otherwise }\end{array}$ & - \\
\hline
\end{tabular}

\section{ETB: Ethiopian Birr, C: Continuous; D: Dummy variable}

Accordingly, the red pepper supply model to be specified in this study is taken the following form. Quantity of red pepper supplied collected raw data were analyzed by applying the Micro-soft Office Excel and the Statistical Package for social Science (SPSS) version 20.

\section{Model specification}

As the dependent variable, quantity of red pepper supply is a continuous variable the appropriate model is the OLS [7].

OLS regression is specified as:

$$
Y_{i}=\alpha_{i}+\beta_{1} x_{1}+\beta_{2} x_{2}+\beta_{3} x_{3}+\ldots \ldots \ldots \ldots+\beta_{i} x_{i}+u_{i}
$$

Where:

$\mathrm{Yi}=$ quantity of red pepper supplied to market

= Intercept

$=$ Coefficient of ith explanatory/independent variable

$=$ Vector of explanatory variables

$=$ Disturbance term

In this study the factors that affect the supply of red pepper to the market is estimated using the Multiple Regression Model (MRM). The main reason multiple linear regression model was used is to identify the most important factors that are associated with the amount of red pepper supplied by producer households in the area, and hence it enables to estimate how the included variables are related. The estimated coefficients indicate the effect of a change in the independent variables on the dependent variable [6].

This model has both dependent and independent variables. The dependent variable is the quantity of red pepper supplied to the market. It is a continuous variable. 


\section{$Q S R P=f(E D L H H, P L A F R P P, F A M S Z, D F M$} Where;

QSRP: Quantity of red pepper supplied to the market

EDLHH: Education level of Household head

PLAFRPP: proportion of land allotted for red pepper production

\section{FAMSZ: Family Size of household}

DFM: distance from market

API: Average input price of red pepper

\section{ALP: Average lagged price}

\section{DIS: Disease}

EXPHH: experience of Household head on red pepper production (Table 1)

For this particular study, Variance Inflation Factor (VIF) and Contingency Coefficient (CC) are used to test the existence of multicolliniarity for association among the continuous variables, and shows how the variance of an estimator is inflated by variables colinarity [7] and Contingency coefficient (CC) is used to check multicollinearity or association between dummy variables. For heteroskedasticity presence Breusch-Pagan test approach, is used.

\section{Results and Discussion}

This chapter presents the major findings of the study and it has three main sections. The first section deals with socio-economic characteristics of red pepper producers and traders. The second section presents market structure, conduct, and performance of red pepper. The third section is about the results of econometric analysis which contains the determinants of market supply of red pepper.

\section{Socio-economic characteristics of red pepper producers and traders}

In this part of the thesis, socio-economic characteristics of red pepper producers and traders are presented and discussed. First the socioeconomic characteristics of red pepper producers were presented, followed by the socioeconomic characteristics of traders.

Socio-economic characteristics of red pepper producers:Sample size of red pepper producer households considered during the survey was 120 . As shown in Table 2, out of total household heads interviewed $92.5 \%$ were male headed households while $7.5 \%$ were female headed households (Table 2). This is well approved by Bezabih and Hadra who reported less opportunity to females in Ethiopia where only two female households have participated from the total of 141 respondents. Wolday, who indicated household size have had significant positive effect on quantity of marketed teff. Similarly Bezabih and Hadera have also witnessed that different sources of labor are employed in horticultural production of eastern Ethiopia where family labor takes the lion share for labor allotments.

The result in Table 3 shows that the average land holding size of the respondents was 1.16 ha which is lower than the national average holding size per household 1.25ha [5].

Owing to inequitable access to information, large proportion of market power is captured by traders who have better access to mobile technology which favored traders to adverse risks of loss to this product. Access to market information is extremely limited in the Ethiopian grain market. At the producer level, farmers have very limited information on price prevailing even in nearby markets (Table 4).

Table2: Demographic Characteristics red pepper producers.

\begin{tabular}{|c|c|c|c|}
\hline Variable & Description & Frequency & Percentage (\%) \\
\hline \multirow[t]{2}{*}{ Sex } & Male & 111 & 92.5 \\
\hline & Female & 9 & 7.5 \\
\hline \multirow[t]{3}{*}{ Marital Status } & Single & 10 & 8.3 \\
\hline & Married & 100 & 83.3 \\
\hline & Widowed & 10 & 8.3 \\
\hline \multirow[t]{2}{*}{ Age } & Age group (24-50) & 97 & 80.7 \\
\hline & Age group (>50) & 23 & 19 \\
\hline \multirow[t]{3}{*}{ Education } & Primary school (0-4) & 63 & 52.5 \\
\hline & Secondary school (5-8) & 50 & 41.6 \\
\hline & High school (9-12) & 7 & 5.8 \\
\hline \multirow[t]{4}{*}{ Family Size } & Small family size $(<4)$ & 6 & 4.9 \\
\hline & Medium family size (4-6) & 49 & 40.9 \\
\hline & Large family size (7-10) & 57 & 47.5 \\
\hline & Very large family size $(>10)$ & 8 & 6.6 \\
\hline
\end{tabular}


Table 3: Access to extension service and market information.

\begin{tabular}{|c|c|c|c|}
\hline Variables & Min. & Max. & Mean \\
\hline Total Land Size (ha) & 0.5 & 4 & 1.1573 \\
\hline Experience of HHH on farm (Years) & 5 & 45 & 17.6833 \\
\hline Experience of HHH off farm (Years) & 0 & 11 & 0.63961 \\
\hline
\end{tabular}

Table 4: Access to extension service and market information.

\begin{tabular}{|c|c|c|c|c|}
\hline Variable & $\mathbf{N}$ & Description & Frequency & Percent \\
\hline Access to Extension Service & 120 & Yes & 114 & 95 \\
\hline \multirow{2}{*}{$\begin{array}{l}\text { Access to Market } \\
\text { Information }\end{array}$} & 120 & Yes & 98 & 81.7 \\
\hline & & No & 22 & 18.3 \\
\hline \multirow{4}{*}{$\begin{array}{l}\text { Source of Market } \\
\text { Information }\end{array}$} & & 1 Other red pepper trader & 34 & 28.3 \\
\hline & & 2 Personal observation & 19 & 15.8 \\
\hline & & 3 Telephone & 55 & 45.8 \\
\hline & & 4 Broker & 12 & 10 \\
\hline
\end{tabular}

Socio-Economic characteristics of red pepper traders: Table 5 summarizes the socio-economic characteristics of traders in terms of gender and marital status. The survey result indicates that, 64\% red pepper traders were males. About 72 percent of Table 5: Socio-economic characteristics of sample traders (dummy variables).

\begin{tabular}{|c|c|c|c|}
\hline Variable & Description & Frequency & Percentage (\%) \\
\hline \multirow[t]{2}{*}{ Gender } & Male & 16 & 64 \\
\hline & Female & 9 & 36 \\
\hline \multirow[t]{2}{*}{ Marital Status } & Single & 7 & 28 \\
\hline & Married & 18 & 72 \\
\hline
\end{tabular}

Table 6: Socio-economic characteristics of sample traders (Continuous variables).

\begin{tabular}{|c|c|c|c|c|c|}
\hline Variables & N & Min. & Max. & Average & S.D. \\
\hline Age & 25 & 27 & 51 & 40.64 & 6.45 \\
\hline Education level & 25 & 2 & 12 & 8.44 & 2.86 \\
\hline Family Size (in No) & 25 & 2 & 9 & 5.4 & 1.83 \\
\hline Experience (in No of years) & 25 & 3 & 12 & 7.36 & 2.59 \\
\hline
\end{tabular}

Market channels, conduct, and performance of red pepper

Marketing channels of red pepper: The main marketing channels identified from the point of production to the final consumer through different intermediaries were:

Channel I: Farmers Consumers (3\%)

The result shows that in this channel a total of about $6600 \mathrm{~kg}$ red pepper is transacted /marketed. As a result the channel them were married, and 28 percent were single. This is supported by IFAD [8] report that shows in sub-Saharan countries women has less participation in trade activities (Table stands as the least (8th) marketing channels in terms of volume.

Channel II: Farmer Cooperative Consumers (5\%)

In this channel a total of $11000 \mathrm{~kg}$ red pepper is transacted. As a result the channel was found to be the 7 th most important channel in terms of volume.

Channel III: Farmers Processors Consumers (7\%)

In this channel about $15400 \mathrm{~kg}$ of red pepper is sold. This 
channels stands as the 6th important channel in the study area in terms of volume transacted.

\section{Channel IV: Farmers Collectors Consumers (9\%)}

In this channel about $19800 \mathrm{~kg}$ of red pepper is sold. These channels stands as the 5th important channel in the study area in terms of volume transacted.

\begin{tabular}{|c|c|}
\hline Channel V: Farmers & Wholesalers \\
\hline
\end{tabular}

In this channel about $22000 \mathrm{~kg}$ of red pepper is sold. These channels stands as the 4 th important channel in the study area in terms of volume transacted.

Channel VI: Farmers Wholesalers Processors Consumers (17\%)

In this case the raw red pepper is sold to consumers by the processors after value addition processing is carried out. In this channel about $37400 \mathrm{~kg}$ of red pepper is sold. These channels stands as the 3rd important channel in the study area in terms of volume transacted.

\section{Channel VII: Farmers Collector Wholesalers Consumers (19\%)}

In this channel a total of $41800 \mathrm{~kg}$ red pepper is transacted. As a result, the channel was found to be the 2 nd most important channel in terms of volume.

Channel VIII: Farmers Retailers Consumers (30\%)

In this channel about $66000 \mathrm{~kg}$ of red pepper is sold. These channels stands as the 1st important channel in the study area in terms of volume transacted.

\section{Market conduct of red pepper:}

Pricing Mechanism (Table 7): Mostly payment was made at a spot and after some hour the red pepper markets was takes place. Purchasing of red pepper done with credit by collectors and hence actual payment may be completed after the red pepper was transferred for respective customer; whereas when the products were sold directly by the processors hand to hand payment was used. The current finding was in agreement with red pepper payment strategy of farmers in Alaba and Silte woreda [9].

Table 7: Price setting mechanisms of red pepper in the study area.
Payment strategy (Table 8): With respect to market conduct it is not only the price setting strategy and the payment mechanisms but also misconducts both from traders and producers were identified. This is especially in relation with weighing the product. The results from both the household's survey and FGDs and KIIs indicated that during the marketing of the red pepper both traders and farmers cheat each other. This cheating from the side of the traders is by their attempt to minimize the volume/weight of the product during weighing, which was the major activity they usually do taking the advantage of the knowledge of farmers and mixing other variety of red pepper from neighboring areas. On the other hand, farmers cheat traders by watering red pepper and adding other foreign materials so as to increase the volume/weight of the pepper that had a great impact on the quality of the product. A farmer may use different methods of checking the weighing scale before selling. The mechanism may be checking one's weigh and comparing it at different weighing scales (or some weighing red pepper on different weighing scales). However, traders manipulate the weighing scale and all traders seem to talking the same language, cheating a minimum of $5 \mathrm{~kg}$ per qt. If the farmer refuses to sell, traders start to discuss on kilogram instead of price with farmers and with the intermediation of collectors.

\section{Market performance of red pepper}

Marketing costs and benefit shares of actors in red pepper value chain: The arrangement of marketing cost revealed that farmers cost is the highest cost from the other actors. This is due to the higher cost of inputs used by red pepper farmers for production. Thus, the cost of input is the highest amount followed by processors cost and wholesalers cost.

A red pepper value chain actor adds value to the product as the product passes from one actor to another. In a way, the actors add value on the product through improving the quality by sorting, removing dusts and other trashes, changing the form, packing and time utility. Traders took a total of $87.75 \%$ out of the total profit margin; specifically, among traders, processors profit margin constitutes the highest share (30.71\%) followed by retailors $(20.49 \%)$. While farmers, doing all the work of producing red pepper and bearing the associated risks, took $12.25 \%$ of the profit margin. This impliedly, red pepper producers added $12.25 \%$ of the total value of red pepper in the woreda (Table 9).

\begin{tabular}{|c|c|c|}
\hline \multirow{2}{*}{ Description } & \multicolumn{2}{|c|}{ Red pepper } \\
\cline { 2 - 3 } & No of Resp. (N = 120) & 7.5 \\
\hline Settled by Sellers & 9 & 14.2 \\
\hline Settled by Buyers & 17 & 78.3 \\
\hline By negotiation b/n buyer \& seller & 94 & $\%$ Percent (\%) \\
\hline
\end{tabular}


Table 8: Payment mechanisms of red pepper in the study area.

\begin{tabular}{|c|c|c|}
\hline \multirow{2}{*}{ Description } & \multicolumn{2}{|c|}{ Red pepper marketing } \\
\cline { 2 - 3 } & No of Resp. (N = 158) & 79.17 \\
\hline As soon as marketing takes place & 95 & 19.17 \\
\hline After some hour & 23 & 1.7 \\
\hline Other day after sale & 2 & $\%$ \\
\hline
\end{tabular}

Table 9: Red pepper marketing costs and benefit shares of actors (per $\mathrm{Kg}$ ).

\begin{tabular}{|c|c|c|c|c|c|c|}
\hline \multirow{2}{*}{ Description } & \multicolumn{3}{c}{ Actors } & \multirow{2}{*}{ Horizontal Sum } \\
\cline { 2 - 7 } & Farmers & Collectors & Wholesalers & Retailors & Processors \\
\hline Purchase price & 0 & 46.2 & 48.3 & 49 & 51.2 & 194.7 \\
\hline Total Mktg Cost & 20.6 & 1.5 & 4.75 & 4.3 & 15.8 & 46.95 \\
\hline Sale Price & 56.6 & 51.4 & 62.2 & 64.5 & 106 & 340.7 \\
\hline Market Margin & 56.6 & 5.2 & 13.4 & 15.5 & 54.8 & 145.5 \\
\hline \% share of margin & 38.9 & 3.57 & 9.21 & 10.65 & 37.67 & 100 \\
\hline Profit Margin & 36 & 49.9 & 57.45 & 60.2 & 90.2 & 293.75 \\
\hline \% share of profit & 12.25 & 16.99 & 19.56 & 20.49 & 30.71 & 100 \\
\hline
\end{tabular}

Determinants of red pepper supply

\section{Data diagnosis}

Test for multicolliniarity: In order to check the existence of multicolliniarity problems among continuous explanatory variable, VIF was employed. As all the VIF values of continuous explanatory variables in all models were less than 10 , it shows that there was no serious multicolliniarity problem among continuous independent variables.

Testfor heteroscedasticity: The presence ofheteroscedasticity in this study was checked by using the Breusch-Pagan (BP) test. There was no heteroscedasticity problem in the model. In this specific model, as the Weighted Least Squares (WLS) method requires knowing of the conditional variance on which the weights are based and it is rarely the case, the robust standard errors was used to deal with heteroskedasticity.

The goodness of fit of the model: In this study, the coefficient of multiple determinations (R2) of red pepper model was estimated 0.788 . This means that $78.8 \%$, of the variations in the dependent variable have been explained by the included explanatory variables in red pepper model; and rest determined by error terms.

\section{Determinants of red pepper market supply}

Estimates of the parameters of the variables expected to determine the marketable supply of red pepper are presented in Table 10. The econometric analysis result (Table 10) shows that among the eight (five continuous and one dummy) hypothesized determinants of market supply of red pepper; were found to be significant at $1 \%, 5 \%$ and $10 \%$ significant level. The relationship and the magnitude of the effect of each the significant explanatory variable on the market supply of red pepper is explained below.

Education level of the household head (EDUHH): Education has showed positive effect on red pepper quantity supplied to market with significance level of $10 \%$. This means that, keeping other factors constant, if the education level of the household head increases by 1 year, the quantity of red peppers supplied to the market increases by about $2.183 \mathrm{~kg}$. Astewel found that if paddy producer gets educated, the amount of paddy supplied to the market increases, which suggests that education improves level of sales that affects the marketable supply. This is also in line with previous study of Ayelech, who found that if avocado producer gets educated, the amount of avocado supplied to the market increases. This result coincides with Tefera, that states that education level is positively and significantly affected selling and securing of more income from bamboo in Sheka, Ethiopia. Amare, also reported that education level of farmers exhibited a significant and positive effect on the marketed surplus of pepper.

Proportion of land allocated for red pepper production (PLAFRPP): The result shows that proportion of land allocated for red pepper production influenced the quantity of supply of red pepper to the market positively at $1 \%$ significance level. Other factors being constant; if proportion of land allocated for red pepper production increases by one hectare, the amount of red pepper supplied to the market increases by $241.740 \mathrm{~kg}$. The result of this study goes along with the findings of former studies. For instance, the finding of Kindie, Rehima, and Wendmagegn found that the amount of sesame, red pepper, and coffee respectively, 
produced per hectare of land by household affected market supply of each of the commodities significantly and positively. In support of the finding here, Kindie and Bosena indicated that the area of land allocated for sesame and cotton production in Metema District significantly and positively affected farm level market supply of sesame and cotton respectively.

Average input price of red pepper 2016 (AIP): The econometric analysis result in Table 10 shows that the input price of red pepper affected the marketed supply of red pepper significantly and negatively (at $1 \%$ significance level). The coefficient for the price of red pepper indicates that, other factors being constant, as the input price increases by one birr, the quantity of red pepper supplied to the market will decrease by $0.029 \mathrm{~kg}$. The increasing price of agricultural inputs in the woreda is not only the production but it is also marketing problem farmers faced while buying agricultural inputs in the market prior to production. Thus, the increase in the price of input forces the farmers not only to reduce the intensity of input use (quantity of input) but also force them to switch to private dealers where there is no assurance of the quality. This in turn resulted in lowering yield and marketed surplus. Thus, the higher price requires due attention by the government.
Average lagged price of red pepper 2015 (ALP): As hypothesized, the model result shows that average lagged price positively and significantly affected red pepper quantity supplied to the market at $5 \%$ significance level. This means that, other factors being constant, a one birr increase in the lagged price of red pepper has caused an increase in $1.322 \mathrm{~kg}$ of marketable red pepper. Therefore, this makes the supply to be directly related to the market price. This agrees with various empirical studies regarding the value chain of agricultural commodities. In this regard, study by Goetz on household marketing behavior in Sub-Saharan Africa found a significant and positive relationship between grain price and the probability of quantities sold. Also, Wolelaw [11] identified the major factors that affect the supply of rice at Fogera Woreda and found that price affected marketable supply of rice positively and significantly. In support of the findings of Ayelech on market chain analysis of fruits found that significant positive relationship between last year fruit price and quantity of fruits supplied to the market.

Disease (DIS): Prevalence of disease was one of the production problems encountered by farmers in the study area. Based on its occurrence, the most commonly occurred diseases were root rot disease. The result shows that disease influenced the quantity of supply of red pepper to the market negatively at $1 \%$ significance

Table 10: Estimation of the determinants of red pepper quantity supplied to the market.

\begin{tabular}{|c|c|c|c|}
\hline \multirow{2}{*}{ ssVariables } & \multicolumn{2}{|c|}{ Red pepper } \\
\cline { 2 - 4 } & Coeff. & Std. Err. & T-value \\
\hline (Constant) & 32.622 & 56.502 & 0.577 \\
\hline EDUHH & $2.183^{*}$ & 2.265 & 0.964 \\
\hline PLAFRPP & $241.740^{* * *}$ & 55.434 & 4.361 \\
\hline FAMSZ & 3.388 & 5.115 & 0.662 \\
\hline DFM & -7.275 & 10.373 & -0.701 \\
\hline API & $-0.029^{* * *}$ & 0.007 & -4.143 \\
\hline ALP & $1.322^{* *}$ & 0.601 & 2.199 \\
\hline DIS & $-77.847^{* * *}$ & 15.623 & -4.983 \\
\hline EXPHH & $3.692^{* *}$ & 1.486 & 2.485 \\
\hline
\end{tabular}

${ }^{* * *},{ }^{* *}$, and ${ }^{*}$ are statistically significant at $1 \%, 5 \%$ and $10 \%$, respectively.

Dependent Variable $=$ Quantity (in number) of Red Pepper supplied to the market.

R-squared= for Red Pepper is 0.788 ; and

Adj. R-squared = for Red Pepper is, 0.772

Number of Observation= 120; Std. Err.: is robus

level. The negative sign indicates that the indirect relationship between the diseases and the quantity of red pepper they supplied to the market. Other factors being constant if a disease is occurred, the amount of red pepper supplied to the market decreases by $77.847 \mathrm{~kg}$.

Experience of the household head (EXPHH): the result shows that the experience of the household head influenced the quantity of supply of red pepper to the market positively and significantly (at $5 \%$ significance level). The positive sign indicates the direct relationship between the experience of the household head and the quantity of red pepper supplied to the market. This means that, keeping other factors constant, as the experience of the household head increases by one year, the amount of red pepper supplied to the market increases by $3.692 \mathrm{~kg}$. This could be 
from the fact that mostly in the study area harvesting and planting of red pepper is the responsibility of household head and when farmers got old the probability of harvesting much quantity of red pepper was higher owing to the experience/ specialization of the farmer. This is in line with finding of Addisu, who illustrated as farmers experience increased the volume of onion supplied to market increased.

Traders took a total of $87.75 \%$ out of the total profit margin; specifically, among traders, processors profit margin constitutes the highest share $(30.71 \%)$ followed by retailors $(20.49 \%)$. As a result, producer share were smaller than traders so enhancing producers bargaining power through cooperative was important. Marketing conduct shows that there was breed mix problem in the study area so that secured governments grant for mareko breed was essential [12-18].ions.

\section{References}

- UNDP (United Nation Development Program) (2013) Towards building resillence and supporting transformation in Ethiopia.

- Haji J (2008) An Economic Efficiency and Marketing Performance of Vegetables in Eastern and Central part of Ethiopia Doctorial thesis, Sweden.

- EIA (Ethiopian Investment Agency) (2012) Investment opportunity profile for the production of fruits and vegetables in Ethiopia.

- EEPA (Ethiopian Export Promotion Agency) (2014) Export performance of Agricultural products, Addis Ababa, Ethiopia.

- CSA (2016) Area and Production of crops Annual Statistical Bulletin, Addis Ababa, Ethopia.

- Green WH (2003) Econometric Analysis ( $5^{\text {th }}$ edn). Prentice Hall. Inc, London, UK, pp. 1026.

- Gujarati DN (2004) Basic Econometrics ( $4^{\text {th }}$ edn). McGraw hill Company, In United States Military Academy, USA.
- IFAD (International Fund for Agricultural Development) (2003) Promoting Market Access for the Rural Poor in Order to Achieve the Millennium Development Goals. IFAD's Governing Council, Rome, Italy.

- Mussema R (2006) Analysis of red pepper marketing: The case of Alaba and Siltie in SNNPRS of Ethiopia. M.Sc thesis presented to the School of Graduate Studies, Haramaya University, pp. 105.

- Tadesse A (2011) Market chain analysis of fruits for Gomma woreda, Jimma zone, Oromia National Regional State. M.Sc thesis presented to School of Graduate Studies, Haramaya University, pp. 110.

- Wolelaw S (2005) Factors Determining Supply of Rice: A Study in Fogera District of Ethiopia. An MSc. Thesis submitted to the School of Graduate Studies of Alemaya University, p. 90.

- Hailu H (2016) Value Chain Analysis of Vegetables: The Case of Ejere District, West Shoa Zone, Oromia National Regional State of Ethiopia. Msc thesis presented to the school of graduate studies, Haramaya University, Haramaya, Ethiopia.

- Takele A (2010) Analysis of Rice Profitability and Marketing chain: The Case of Fogera Woreda, South Gondar Zone, Amhara National Regional State, Ethiopia. An MSc Thesis Presented to School of Graduate Studies of Haramaya University, p. 76.

- Emana B (2008) Value chain analysis of horticultural crops in Kombolcha districts of eastern Oromia Region, Ethiopia. A study conducted for Action Aid Ethiopia, Addis Ababa.

- Emana B, Gebremedhin H (2007) Constraints and Opportunities of Horticulture Production and Marketing in Eastern Ethiopia DCG Report No. 46.

- Alemu D, Teklewold H. Marketing of fruits and vegetables: opportunities and constraints in the Rift Valley of Ethiopia. Melkasa \& Debrezeit Agricultural Research Centers, p. 22.

- Birhanu D (2007) Assessment of forest coffee value chains in Ethiopia: A case study in Kafa zone, Gimbo district. Agricultural Science and Resource Management in the Tropics and Subtropics (ARTS). German.

- Endalamaw TB (2013) Indicators and determinants of small-Scale bamboo commercialization in Ethiopia: Institute of International Forestry and Forest Products, Technische Universität Dresden, Germany.

\section{Your next submission with Juniper Publishers will reach you the below assets}

- Quality Editorial service

- Swift Peer Review

- Reprints availability

- E-prints Service

- Manuscript Podcast for convenient understanding

- Global attainment for your research

- Manuscript accessibility in different formats

( Pdf, E-pub, Full Text, Audio)

- Unceasing customer service

Track the below URL for one-step submission https://juniperpublishers.com/online-submission.php 